\title{
Multi-level port resilience planning in the UK: How can information sharing be made easier?
}

Duncan R. Shaw, Nottingham University Business School, Jubilee Campus, Nottingham, UK. (corresponding author) Email: duncan.shaw@nottingham.ac.uk, Tel: +44 (0) 1158467756.

Andrew Grainger, Nottingham University Business School, Jubilee Campus, Nottingham, UK. Andrew.Grainger@nottingham.ac.uk.

Kamal Achuthan, Centre for Transport Studies, Department of Civil, Environmental and Geomatic Engineering, University College London, k.achuthan@ucl.ac.uk.

\begin{abstract}
Port resilience planning is a subset of the wider disaster resilience literature and it is concerned with how port stakeholders work together to make port systems more resilience. Port stakeholders include government departments, the port operator, ship operators, importers, agents and logistics firms. Ports are vital for the operation of cities and whole countries, especial island nations like the UK. Single port systems are multi-level systems with complex operational-level relationships and interdependencies. Additional levels to this include government and the policy-level. Preparing for the crises and disasters that might befall ports requires information sharing between stakeholders about key dependencies and alternative actions. The complexity of ports presents barriers to information sharing; as do commercial and political sensitivities. This paper uses a multi-level case study on the UK's system of ports to propose an approach to information sharing that uses the subjectivity of information from a supplier's perspective and from a user's perspective to reduce barriers of complexity, confidentiality and political sensitivity.
\end{abstract}

Keywords: complex systems, port resilience planning, information sharing, operational and policy-level contexts.

\section{Introduction}

As an island nation, the UK depends upon its ports and $97 \%$ of the UK's trade in goods relies upon them. The UK imports $50 \%$ of its food of which $91 \%$ comes by sea. The largest UK ports are highly specialised with the top ten handling $69 \%$ of all tonnage. For example, Felixstowe handles $40 \%$ of all container traffic. Several of the UK's major UK power stations and oil refineries are dependent on dedicated linked maritime facilities (including Milford Haven, Southampton and the Port of Immingham). The UK's dominant ports often handle twice as much cargo as the next port which specialises in oil, gas, containers or ferries. So it would be difficult to replace the capabilities of a dominant port if it were lost (Grainger and Achuthan, 2014). Any prolonged failure at one of the key ports will significantly affect the UK's supply chains and consumers. Potential risks to ports include tidal surges, marine accidents, sustained adverse weather, acts of terrorism, industrial action and other disasters. On 5th December 2013 a one in 500 year tidal surge almost destroyed most of the UK's east coast ports (Powell, 2015). These ports, between the Tyne and Dover, make up 57\% of the UK's food imports (Achuthan et al., 2015). All UK major ports are highly specialised, and should a major disruption at any one of the dominant ports arise, it is unlikely that additional capacity within the UK can be found without significant advanced planning, i.e. without 'port resilience planning' (ibid).

Maritime ports are complex operational systems with many different types of stakeholders, for example shipping lines, terminal operators, harbour masters, resident firms who store or process cargoes, port users, local residents, transport firms and logistics service providers (Becker and Caldwell, 2015). Their interests are seldom aligned and there is an urgent need for the UK ports sector to improve its resilience planning (Davies, 2014, Achuthan et al., 2015). In this paper we investigate the complex social system of dependencies and information requirements that form a modern port ecosystem.

Here we define resilience in terms of joined-up information sharing between stakeholders and we suggest ways to enable this. Our research objective is to understand how information sharing can be made easier in the context of port resilience planning. First we describe the theoretical background of disaster resilience, its links to the port resilience planning literature and our focus on information sharing. Next we explain our research process, which uses a multi-level case study approach based on hermeneutics; a method which is appropriate for examining the complex inter-relations between the many stakeholders of a single port and higher levels of interport dependencies. Then we use a rich and diverse set of examples from our research participants to highlight many of the obstacles to information sharing in the form of 'silos' that separate stakeholders. Silos that have their basis in the complexities of the port system itself. We describe how we arrived at a novel conceptualisation of information sharing in this domain. Finally, we use our theoretical findings to suggest how obstacles to 
information sharing may be avoided in port resilience planning; and how this might benefit researchers and practitioners working in this area.

\section{Theoretical Background}

\subsection{Resilience and disaster resilience}

The literature on resilience has roots in many fields including mathematics, physics, ecology, engineering, climate change, metallurgy, strategic management, economic, supply chain management, psychiatry and psychology (Aldunce et al., 2014; Bhamra et al., 2011; Manyena, 2006; Bahadur et al., 2013). Here we focus on the field of disaster management where the concept of resilience has been used increasingly in recent years. Especially after the adoption of the United Nations' Hyogo Framework for Action 2005- 2015 (UN/ISDR, 2007).

The term resilience is commonly defined as the capability of a system to return or "bounce back" to a state of equilibrium after some disruption or perturbation. The system in question could be an individual's mental or physical state, a human social system or a natural system. The term has recently expanded to include the idea of returning to some other stable state that is not the same as the initial state of equilibrium. In the disaster resilience literature this means not just bouncing back but accommodating a disruption and improving on the previous equilibrium state (Aldunce et al., 2014) or "bouncing forward" and developing a system after a disaster (Manyena et al., 2011). Within the disaster resilience literature the term has also been used in many different contexts such as the resilience of communities (Norris et al., 2008); complexity and complex adaptive systems (Welsh, 2014; Comfort et al., 2001); "fragile" and "failed" nation states (Manyena and Gordon, 2014)); emergency planning (Crichton et al., 2009); and information systems (Chewning et al., 2012). Each context is used to make sense of resilience phenomena in different ways and this has led to many subtle variations in the development of the resilience literature.

\subsection{Port resilience and port resilience planning}

Here we look at resilience in the domain of sea ports and their communities of stakeholders. Ports are a key component of cities, and disasters affect them as much as they affect cities. Arguably ports are a significant subject within the research into disaster resilience because ports are commonly used to transport material help to effected communities.

The literature on port resilience is developing rapidly because ports are seen as vital for the operation of cities and whole countries, especial island nations like the UK (Achuthan et al., 2015). Recent research on port resilience includes the roles of different port stakeholders in resilience planning (Becker and Caldwell, 2015); managing supply chain disruption using structural equation modelling (Loh and Thai, 2015); resiliency metrics for maritime transportation systems (Omer et al., 2012); the vulnerability of port to failures using the perspectives of interdependency and co-opetition (Hsieh et al., 2014); risk-based strategic decision-making for investments (Mansouri et al., 2010); business continuity planning which identifies alternative ports (Akakura et al., 2015); port capacity bottlenecks (Trepte and Rice, 2014) and simulating port network capacity in disaster response scenarios (Paul and Maloni, 2010). A significant characteristic of ports that all these papers include in their investigations is the notion of a port's capabilities to transfer people and cargoes between land and sea transportation. The literature is concerned with the effect of a crisis on the ability of different ports, or systems of ports, to transfer people and cargoes using different modes of transference, e.g. containers, roll-on-roll-off systems, bulk material handling equipment or a cruise passenger terminal. Also, much of the resilience literature includes planning of some sort because resilience itself includes some notion of being ready for, and also mitigating, the effects of a crisis. For example, learning how to plan from past crises (Crichton et al., 2009).

But within the literature there has been little research into how information is shared. Bharosa et al. studied how information was shared for coordination purposes, especially with respect to the obstacles to sharing whilst coordinating information for disaster response exercises (2010). These obstacles included organisational silos, privacy issues, lack of incentives to share, security issues, conflicts of interest, lack of opportunity, a lack of platforms to share with, information overload and information quality. A significant insight was the mismatch between the information requirements of an information user and the understanding of this by the information provider. But the focus of Bharosa et al. was on crisis response rather than resilience planning purposes. Chewning et al. investigated how information systems facilitate information sharing with respect to communicating with the public, but again this was concerned with response rather than resilience planning (2012). The same is true for a study on the relationship between trust and information sharing by Ibrahim and Allen (2012), or an investigation of information sharing in high velocity environments by Allen et al. (2014) and a development of emergency data standards for information sharing by Chen et al. (2008). 
Interdependency is also an area that is starting to be investigated within the literature. The interdependency of port stakeholders is important for two reasons. First, port stakeholders and their assets rely on each other for resources that include port services, the supply of people and cargo, and information. A crisis that makes some resource unavailable may in turn remove other resources from the port system (Hsieh et al., 2014). Second, the interdependency and interlinking of port stakeholders suggests the possibility of mutual assistance and help with alternative resources (Akakura et al., 2015). Unfortunately the complex interdependencies of stakeholders and their operations produce emergent phenomena that are difficult to make sense of (Comfort et al., 2001; Welsh, 2014).

In summary, the disaster resilience literature includes the sub-domain of port resilience planning and within this there has been little research on information sharing in terms of interdependencies between port stakeholders. Here we focus on how interdependent port organisations share information between each other for resilience planning purposes and with a specific focus on the port system's capability to transfer people and cargoes between land and sea transportation.

\section{Research Method}

\subsection{Research process}

Our objective was to understand how information sharing can be made easier so as to improve resilience planning. So we chose to take a qualitative approach as we were interested in subjective questions of 'how' and 'why' rather than of 'how many'. Our focus was to study different stakeholders' requirements for information, and the information that they held, which was subjective. In seeking to answer questions of 'how' and 'why', we followed Yin and used a case study approach (2003). Case studies are useful for investigating contemporary phenomena, which researchers have no control over (Eisenhardt, 1989). They are also a valid approach for information systems research (Benbasat et al, 1987; Lee, 1989). A case study approach was especially suited to our focus on business relationships between different stakeholder organisations. We were concerned with dynamic phenomena so we used several different data collection methods and many different data sources (ibid).

\section{Data}

We collected data between January 2010 and March 2016. We held semi-structured interviews and meetings with the managers and staff of the Department for Transport (DfT), port landlords and other port stakeholder organisations. We selected the interview participants so that they covered a range of UK ports as well as a range of different types of port stakeholder organisations, i.e. government departments, port landlords, harbour masters, logistics firms and ship operators. Table I lists our main meetings, workshops and presentations with research participants. The interviews lasted between 30 minutes and 2 hours. In addition to interviews we also held validation meetings to present our findings to participants and listen to their feedback, and we frequently published validation document to test our ideas and gain comments (for example Grainger and Achuthan, 2014) Also, one of the authors was seconded from his university to the DfT for six months during this period to advise on simulating crises in ports. The secondment plus the interviews, meetings and validation documents provided multiple opportunities for unstructured exploration of different aspects of the case. They gave us repeated and frequent opportunities to test our emerging conceptualisation of the case phenomena. All through the investigation we held informal email and telephone conversations with the participants; especially with the DfT. The participants gave us valuable feedback on how well our ideas fitted with their interpretations of the role of information sharing in port resilience planning; or how relevant our ideas were (Suddaby, 2006). For example, by presenting our developing ideas in research validation documents to UK government departments and port resilience stakeholder organisations (Grainger and Achuthan, 2014; Achuthan et al., 2015). The length of the project led to prolonged relationships with many of the case participants, which also helped to increase trust the levels of disclosure.

\begin{tabular}{|l|l|l|}
\hline \multicolumn{1}{|c|}{ Stakeholder type } & \multicolumn{1}{|c|}{ Stakeholder(s) } & \multicolumn{1}{|c|}{ Type of meeting } \\
\hline $\begin{array}{l}\text { Satellite data } \\
\text { sources }\end{array}$ & Satellite data providers & Workshop \\
\hline Ferry operator & DFDS - Immingham & Interview \\
\hline \multirow{3}{*}{$\begin{array}{l}\text { Government } \\
\text { department }\end{array}$} & Cabinet Office & Interviews \\
\cline { 2 - 3 } & Defra - two workshops and an interview & Workshop \\
\cline { 2 - 3 } & $\begin{array}{l}\text { DfT - multiple interviews, meetings and informal } \\
\text { communications }\end{array}$ & Interview \\
\hline
\end{tabular}




\begin{tabular}{|c|c|c|}
\hline & $\begin{array}{l}\text { DfT-Big Data workshop with Resilience Head and } \\
\text { data analysts }\end{array}$ & Workshop \\
\hline & Meeting with DfT and DECC & Workshop \\
\hline \multirow{4}{*}{ Industry Association } & British Harbour Masters Association & Conference \\
\hline & International Association of Maritime Economists & Presentation \\
\hline & UK Major Ports Group - three meetings & Interview \\
\hline & $\begin{array}{l}\text { UK Major Port Group, British Ports Association and } \\
\text { UK Chamber of Shipping }\end{array}$ & Workshop \\
\hline \multirow{6}{*}{$\begin{array}{l}\text { Mixed stakeholder } \\
\text { group }\end{array}$} & DfT hosted workshop with UK port sector & Workshop \\
\hline & Montgomery Exercise & Workshop \\
\hline & South East Ports Group - two workshops & Workshop \\
\hline & Tidal surge workshop & Workshop \\
\hline & UK Ports and DfT & Workshop \\
\hline & $\begin{array}{l}\text { Multi-stakeholder validation workshop hosted by the } \\
\text { DfT }\end{array}$ & Presentation \\
\hline \multirow{7}{*}{ Port operator } & Ramsgate Port & Interviews \\
\hline & Dover Port & Interviews \\
\hline & Grimsby - ABP - interviews and a workshop & Workshop \\
\hline & Harwich Haven Port & Interviews \\
\hline & Immingham - interviews and a workshop & Interviews \\
\hline & $\begin{array}{l}\text { Port of London Authority - multiple meetings, } \\
\text { workshops and interviews between } 3 \text { February } 2011 \\
\text { and } 4 \text { September } 2013\end{array}$ & Interviews \\
\hline & Tilbury Port Health & Meeting \\
\hline \multirow{6}{*}{ Port stakeholder } & Cockett Marine Oil Ltd & Interviews \\
\hline & Estuary Services Ltd & Interview \\
\hline & London Central Cruise Moorings & Interview \\
\hline & Svitzer Towage & Interview \\
\hline & Tilbury Container Services & Interview \\
\hline & Tilbury Police & Interview \\
\hline Power station & Drax & Interview \\
\hline Transport Minister & UK Minister Stephen Hammond & Presentation \\
\hline Workshop & Dover Harbour Board & Interview \\
\hline
\end{tabular}

Table I: Summary of main meetings with ports stakeholders and their organisational types.

Data was collected from meeting reports, meeting notes and telephone conversations, together with informal and chance conversations that were supplemented by the participants' internal reports and the content of their websites. We interviewed participants in their offices or the offices of other participants, for example meetings at the DfT's offices where we met the UK Major Ports Group, the UK Chamber of Shipping and the British Ports Association to ask them to urge their members to come to our validation workshop in September 2015. All interviews and meetings were recorded using detailed paper notes because of the commercial and politically sensitive nature of some of the subjects of discussion. All notes were then discussed between at least two of the three authors to minimise researcher bias and to triangulate for emerging ideas.

\section{Data Analysis}

We chose a social science approach because port resilience planning intersects the different social systems that are focused on UK ports including business, public policy and administration, transport and law. We used a 
qualitative approach because the 'needs' to share more data (greater resilience) and the barriers to doing so, for example privacy, were based on the diverse social contexts of the different stakeholders at different levels of UK society. The individual and social contexts of data users, their work roles, were linked in some way to their data requirements as well as to their capabilities to supply data and their constraints in doing so.

Also, we chose a qualitative approach because we were studying complex organizational processes and we wanted to show 'what precedes what'. This approach allowed us to 'cycle back and forth' between variables and processes (Miles and Huberman, 1994). We used an interpretive approach that was based on Klein and Myers' principles for conducting and evaluating interpretive field research (1999). These principles are based on the philosophical perspective of hermeneutics. Hermeneutics is a major branch of interpretive philosophy and Klein and Myers' principles are designed to support the evaluation of interpretive case study research. Hermeneutics is based on the idea that an understanding of a whole system comes from contrasting preconceptions and new understandings gained from studying a system's parts and their different interrelationships. In hermeneutics the process of interpretation is circular. Researchers move from initial understanding of the parts, to an understanding of the whole. Then from an understanding of the whole to contrasting it with the surrounding context of the whole and finally, back to a more developed understanding of the parts (ibid). Hermeneutics is a process because it examines in stages the interrelationships between parts and whole, parts and parts, and the whole and its environment. It is a cyclical process because it repeats, and each cycle improves the researcher's understanding because of access to new data and new conceptualisations of that data. This approach is particularly useful for analysing complex cases because researchers are boundedly rational (Simon, 1997). The bounding of researchers' information gathering and processing capabilities is mitigated by a repeating cycle of studying different dyadic relationships in a much wider system; which is much too complex to be perceived and considered at once.

In our investigation we cycled around a hermeneutic circle, between the policy level of the regulator, the whole port level of the port landlord and the operational level of individual port stakeholder firms. This enabled us to perceive an interdependent whole (Klein and Myers, 1999; Chalmers, 2004). We chose the case as an extreme case because its multiple levels of government, port landlord and port operations firms represented port resilience planning phenomena for a whole country (Eisenhardt, 1989). The case was special because of our access to all three levels. This allowed us to perceive the multi-level contexts of how data was used and produced which cases with other system boundaries would not provide (Siggelkow, 2007). Our aim was to build theory, so whilst drawing insights from a single case has external generalisation implications (Lee, 1989), at the start of theory generation a single case is appropriate (Benbasat et al, 1987). Also it does not degrade analytic or theoretical generalisation (Robson, 2002). Hermenutics is particularly suited for investigating social phenomena, like port resilience, which depends on the complex interactions of stakeholders in many different operational, commercial, governmental and legal systems. So a systems approach that mitigates complexity with cycles of testing and analysis, the expertise of stakeholders and an acknowledgement of the researchers' influence is appropriate.

We followed Klein and Myers' principles for conducting and evaluating interpretive field research based on the hermeneutical cycle (1999). We will describe these overlapping and mutually supportive principles here:

1. The Fundamental Principle of the Hermeneutic Circle - This principle is based on the idea that humans interpret the data from their senses by repeatedly cycling through studies of interdependencies between the parts of a focal system and the whole. Parts include the researchers and the participants as well as data, organisations and material objects on different scales. This fundamental to all Klein and Myers' principles.

2. The Principle of Contextualization - This principle highlights a need to consider the case in terms of its social and historical 'back story'. Researchers must reflect on how the phenomenon that they witness emerged and why this might be so.

3. The Principle of Interaction Between the Researchers and the Subjects - This principle emphasises the need to assess how the interactions between the researchers and the participants socially constructed the case data. Researchers should become self-conscious about their own assumptions and question them.

4. The Principle of Abstraction and Generalization - This principle requires researchers to identify links between the idiographic findings that emerge from their particular data and the wider literature. These links help to theoretically test any contribution and also to site it in appropriate literatures.

5. The Principle of Dialogical Reasoning - This principle requires researchers to be transparent about their preconceptions, prejudices and preconceptions, to explain 'how were we thinking when we started this research?'. Describing how and why the initial conceptual lens of their investigation changed helps researchers and their readers to see how different concepts promoted an understand, or misunderstanding, of the situation in the case. 
6. The Principle of Multiple Interpretations - This principle requires researchers to look out for the potential for researchers and participants with different perspectives on the same situation to have different interpretations. This is similar to the Rashomon Effect (Roth and Mehta, 2002) and produces both a potential for bias and also a potential for special data and insight.

7. The Principle of Suspicion - This principle requires researchers look out for socially created distortions of participants' accounts of the case situation. Researchers should not think of this in terms of truths or falsehood but instead they should consider how commercial or political sensitivities might systematically 'sway' the words of the actors. For example with common 'figures of speak', routines, ideas, standards or protocols. This is a particularly subtle demand on researchers but it presents an opportunity for a deeper understanding of the social forces at work in the case.

In keeping with the multi-level and cyclical nature of hermeneutics, when researchers follow these principles they must also consider how these principles interrelate and add to the whole of the research process rather than being separate items in a check list. The research process and its insights must be plausible to readers both in parts and as a whole.

\subsection{The Case Site}

In 2011 the UK Prime Minister commissioned Oliver Letwin, the UK's Minister of State for Government Policy, to review sectoral resilience across government. He concluded that a tidal surge was one of the very real risks the UK faced. As a result of this the Minister commissioned the Department for Transport (DfT) to prepare plans to "dry out ports" (Davies, 2014). This work was led by the DfT, sponsored by the highest levels of the UK Government and regularly checked at meetings of the UK's 'COBRA' committee (Gardiner, 2002). Our case study focused on this work.

\section{Case analysis}

\subsection{Data that port stakeholders need for resilience planning}

Table II shows some of the information that port operators told us they would find useful for resilience planning purposes. Access to various information sources was not straight forward because of commercial privacy issues and other sensitivities. Moreover, some information was out of date or of insufficient quality to take action. For example, lack of detail in topographical information proved challenging when considering where to place sandbags as a preventative flood-fence measure. Cargo information included the contents, owner, destination and next stage of goods or passengers. Traffic movement information included characteristics of vehicles and crew for road, rail and sea transportation. Port asset and infrastructure information included the characteristics and location of the different handling, storage and transport machinery that make up the port itself. Environmental information included characteristics of the port's external environment that might affect its ability to function. Network linkage information included characteristics of the wider system of ports including competitor ports. A common theme in these information types was some description of the capabilities of different parts of the port system to function as a means of moving goods and people. This included parallel means in the form of competitors or alternative service providers, routes and modes of transport. 


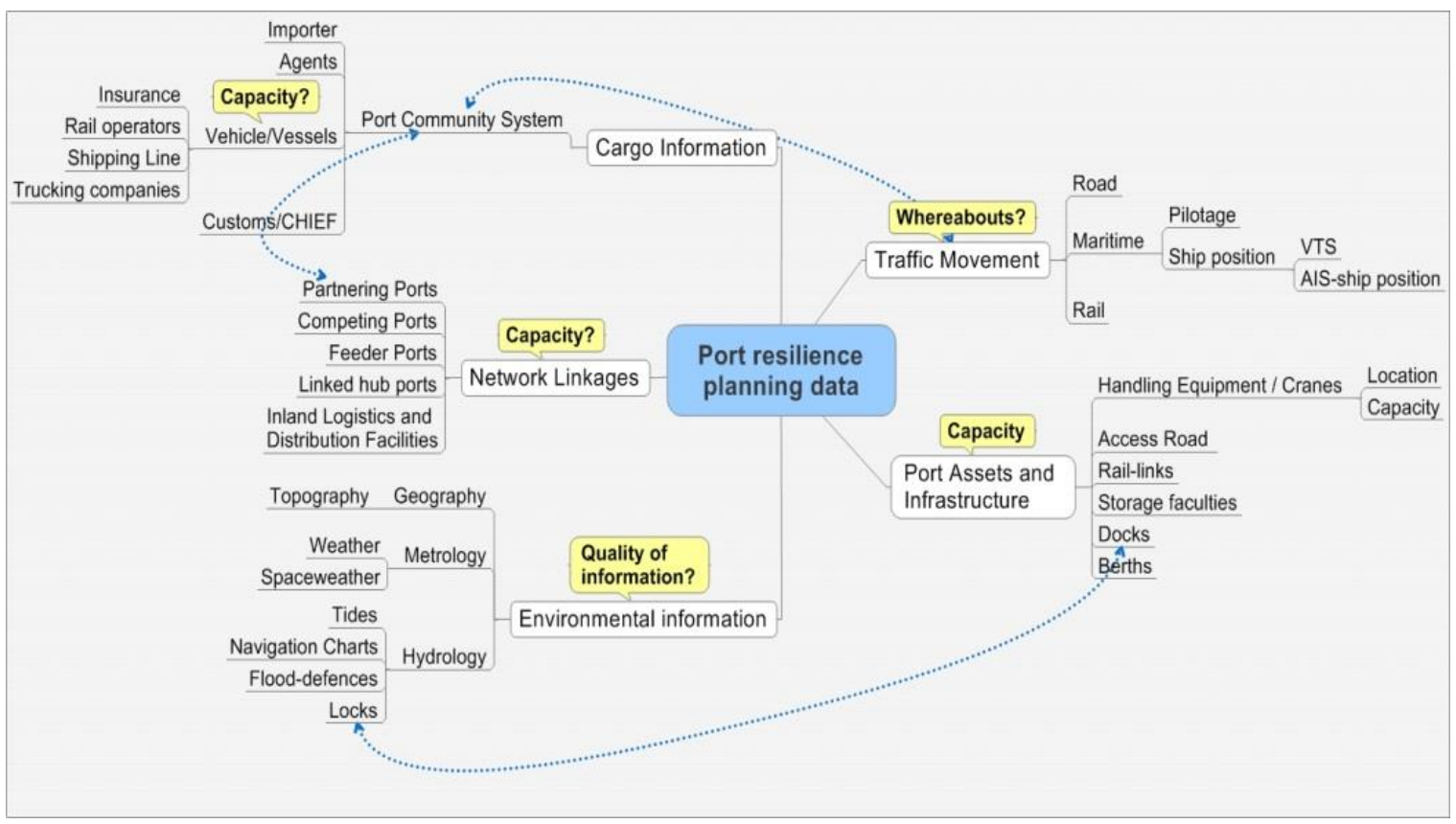

Table II: Many different types of information were required for resilience planning

4.2 The information required for port resilience planning is about 'secondary risks', the key system dependencies.

As we talked to people that were responsible for initiating port resilience planning across the UK's system of ports we found that critical systems relied on key dependencies, what our Department for the Environment, Food and Rural Affairs (Defra) participant called 'secondary risks'. These were specific chemicals, spare parts, specialities, communications capabilities, energy and fuel types, materials or information that if destroyed, lost or completely consumed have a disproportionate effect on the whole system or subsystem. Certain people or equipment were also critical dependencies, e.g. specialised handling equipment or certain highly experienced managers. Even key bridges, stretches of road or lengths of train track were system constraints that nullify whole subsystems if they were damaged or removed from use. At the port level, ports themselves specialised (see Table III so the loss of one specialist port to the UK would had a huge effect on the UK's overall port capacity. The top ten UK ports handled $69 \%$ of all port traffic by tonnage. Most of the large ports were highly specialised and the largest of them often handle twice as much cargo as the nearest competitor (Grainger and Achuthan, 2014). The areas of specialisation were cargo types such as oil, gas, containers, and ferries. For example, the Port of Immingham handled most of the UK's coal imports.

\begin{tabular}{|l|r|l|r|}
\hline $\begin{array}{l}\text { Major ports: all oil and gas } \\
\text { traffic }\end{array}$ & \% tonnage & Major ports: dry bulk traffic & \% tonnage \\
\hline Milford haven & 29.9 & Grimsby \& Immingham & 19.9 \\
\hline Southampton & 11.5 & London & 11.3 \\
\hline Forth & 10.5 & Liverpool & 7.8 \\
\hline Tees \& Hartlepool & 9.4 & Clyde & 7.3 \\
\hline Grimsby \& Immingham & 9.3 & Port Talbot & 6.8 \\
\hline All major UK ports & $\mathbf{1 0 0}$ & All major UK ports & $\mathbf{1 0 0}$ \\
\hline & & & $\%$ units \\
\hline All container traffic & $\mathbf{\%}$ units & All ports: accompanied & passenger cars \\
\hline Felixstowe & 40.2 & Dover & 41.5 \\
\hline Southampton & 19.6 & Portsmouth & 11.3 \\
\hline
\end{tabular}




\begin{tabular}{|l|r|l|r|}
\hline London & 8.7 & Holyhead & 7.4 \\
\hline Liverpool & 8.2 & Belfast & 4.4 \\
\hline Medway & 4.2 & Stranraer & 3.5 \\
\hline All ports of UK & $\mathbf{1 0 0}$ & All ports of UK & $\mathbf{1 0 0}$ \\
\hline
\end{tabular}

Table III: The specialisation of UK ports is shown by the top five ports for selected traffic types in 2011 (DfT, 2011; DfT, 2012).

At lower levels too, within each port there were 'concentrations of dependency' where there were key people or equipment. When we tested this idea with representatives of the UK's Defra, DfT and the Department for Energy and Climate Change (DECC). Defra and DfT rapidly agreed. Key bottlenecks in the transport system were in the form of certain roads like the M20 and A2 to Dover Port that all road traffic had to pass through; or certain stretches of the UK rail network between the Drax Power Station and the HIT coal terminal in the Port of Immingham that all coal trains to the Drax power station needed to use. But the resilience specialist from DECC was initially less inclined to agree because fuel for power stations was held in huge stock piles. So any disruption in the flow of fuel would take years to impact energy production. For example, the Drax power station held enough coal stocks for six months and overall the whole sector had enough stocks for more than a year. However, when we expanded the definition of secondary risks to include key people, key cleaning chemicals and other peripheral dependencies then agreement was rapid. In a crisis there may have been a huge amount of coal at a power station but it would have only taken a substantial snow fall to stop key personal from coming to work.

For food-related resilience issues the short shelf-life of foods like fresh vegetables was much more important. For example, in 2015 the Channel Tunnel was repeatedly blocked by refugees at the Calais end (BBC, 2015b). Each time this stopped lorry transport from the UK to France and lorries were directed to queue up on the M20 motorway in Kent, in “Operation Stack” (Highways England, 2015, Kent Police, 2016). Temperature controlled cargo was particularly vulnerable to delay. In some cases the tolerance for delay was as little as a few hours.

In our investigation we found that most port stakeholders did not have the necessary information understand what their secondary risks were. So they could not plan ahead to mitigate the impact of any disruption and aid recovery. The concept of 'secondary risk' was not widely spread in the port industry, so there was no systematic planning for secondary risks. Port stakeholders needed information that would describe the secondary risks associated with their part of the ports system. Their length of track or road; their transport vehicle or fleet; their cargo handling equipment; their storage facilities; their power source; or their skilled personnel. One staff member of global ferry operator told us about an occasion when he needed portable toilets because he needed to accommodate truck drivers for a longer time than was planned. Secondary risk information included operational shipping data, environmental and geographical data, metrological data, human resource data, manufacturing data, capacity and utilisation data, and data about assets and equipment. Much of this data was not available for resilience planning purposes. This left poorly equipped, those people who were concerned with ensuring that ports were operational, (Grainger and Achuthan, 2014).

System resilience requires joined-up working between stakeholders on all system levels. In our study the data that organisations systematically shared for resilience planning purposes was limited. Data sharing was done for normal business purposes, for example between direct supply chain partners. There was virtually no sharing between non-adjacent firms in the supply chains and even adjacent firms shared data in a specialised manner that was not consistent with normal operations. For example, the Port of Immingham did not know if ships carrying coal for the Drax power station were from Murmansk or a Columbian coal supplier. This was important because coal from Murmansk was likely to be frozen, which presented special problems for unloading. This type of fragmentation was due to the port not having 'sight' of the commercial relationship between Drax and the coal supplier. Drax placed an order for coal with a Columbian coal supplier and Drax's shipping agent (a separate firm) booked a berth at the port for a specific time and day. But nobody automatically told the port which coal supplier was used. We were told of another example of fragmented, or not joined-up, information when we visited the Port of Southampton. One of the port's tenants was a car terminal that received trainloads of cars from a car manufacturer every day. Another port tenant was a cruise terminal that loaded and unloaded cruise passengers. When a train full of cars got derailed and blocked the port's road or rail connections then the port operator was concerned about the effect on the cruise terminal. But the commercial relationship was between the car terminal and the car manufacturer, not with the port. The train operator asked the port for permission to enter with a train but the port did not have access to information about future car deliveries. It would had to ask the car manufacturer and it did not have a contact to ask. 
We found that siloes between organisations were the norm because of pressure in normal operations to focus just on efficient working. Port operators, logistics firms and other port stakeholder firms sought to be as efficient as possible, so they sought to minimise system redundancy even in the information that they normally exchanged. They only communicated what was necessary for normal operations. Also, staff in each firm mostly focused on their own responsibilities and did not consider the needs of other firms too much, unless they were direct customers or suppliers. We did find instances of ad hoc sharing of information for mutual help but there is little systematic understanding of this by port stakeholders as a group. For example at the Port of London, harbour masters explained that in instances where the intended berth is not available, they can often draw on underutilised berths elsewhere on the river to temporally moor the vessel until the required berth becomes available. This mutual assistance and the informal information flows that supported it was between separate firms that operated the many berths in the Port of London (PLA, 2016a; PLA, 2016b). another example was when one government inspection agency such as customs or quarantine asked to inspect a cargo, the other agency was also asked if it wanted to look before the cargo was put back into storage. In this example the second inspection agency was prompted. Mostly, information seekers had to take the initiative.

We also found that another type of silo occurred between levels in the UK system of ports. It was a common organisational phenomenon for silos to occur between operational staff and management. A single manager does not know all the details involved in their direct reports' work, and so on for greater separations between manager and worker. But we saw that port landlords and their tenants, the firms that actually did the work of the port needed information sharing between vertical system levels. For example, port landlords took a lead in orchestrating the combined operations of several port firms. They were motivated by wanting to ensure that any disruptions at one facility would not spill over into a different area of activity. In the case Southampton Port wanted to ensure that cruise ship operations were serviced even when a train carrying cars got derailed in the port and jammed-up all access roads. Another example of the need for information sharing between vertical system levels was evident in our conversations with policy makers and operational firms. We noticed one example of information sharing between the DfT and different port stakeholders. In 2010 the East Coast Flood Group was formed to bring together planners from coastal Local Resilience Forums, the Environment Agency, the Met Office, utility firms, the Emergency Planning Society, voluntary sector organisations and lead UK government departments which included DEFRA, the Department for Communities and Local Government, the Minister of Defence, the DfT and the Civil Contingencies Secretariat of the Cabinet Office. The group's objective was to prepare for major natural hazards such as floods and it linked with the UK's Central Government Group for coastal flooding (Powell, 2015). One valuable role that the Group had was as an information conduit between the DfT and the ports sector of the UK's East Coast. The Group acted as a consultative vehicle. It allowed the ports to comment on port-related ideas from the DfT and other government departments. It also gave several government departments the chance to inform policy and later on to test policy in a safe and informed forum.

In summary, we found that information 'silos' impeded three types of information flow to some degree or another:

- $\quad$ along potential Serial Flows, between the port operator, shipping lines, shippers and end-users - inter-firm flow paths and supply chains;

- $\quad$ along potential Parallel Flows between competing ports and their stakeholders to explore scope for mutual aid or alternatives - competition silos and on a higher level different business ecosystem silos;

- $\quad$ along potential Vertical Flows, between management and operations staff or between firms and policy makers - different level silos.

\subsection{The barriers to sharing data about secondary risks are commercial, political and subjectivity}

Having sensitised ourselves to these 'silos' that impeded information flows between different port system stakeholders, we then started to investigate how and why these blockages occurred and we found several categories of barriers. First, the disasters and crises that we discussed with participants were unforecastable, they were emergent phenomena. To some extent an organisation that could forecast a disaster was able to mitigate its potential effects and change it from becoming a disaster to a lesser problem. In our interviews with port operators a key part of their role was to plan. For example, in Southampton the Port operator developed detailed business cases for investing in multi-level car storage to store vehicles for export. At Dover the port invested in traffic monitoring and vessel scheduling. What made these planning activities critical was the scarcity of certain resources, for example, limited port land area to work in or key bottleneck such as loading and unloading between vessels and road vehicles. Our investigation was aimed at extending this ability to plan. The problem for port operators was that some phenomena occurred without warning to them or was completely 
outside of their ability to notice. This problem was echoed for all other stakeholders that we talked to; the staff of firms and government organisations that we interviewed mentioned how 'earlier' warnings of events would be most useful to them, even in normal operations. Or warnings from organisations with a view of the 'bigger picture' or just someone who 'put the pieces together'. For example, in 2008 a container ship carrying a load of cranes broke free and destroyed cranes on Felixstowe Port's quay. This coincided with the toppling of a dockcrane at Southampton Container Terminal, which lead to its temporary closure for a Health and Safety investigation and a clean-up operation (Grainger and Achuthan, 2014). So two key ports temporarily had their capabilities reduced or removed at the same time. Another example was between the combined actions of governments around the world and its emergent effect on port systems. In 2015, when refugees tried to travel to the UK through the Channel Tunnel from Calais they effectively closed the tunnel on several occasions (BBC, $2015 b$ ). The inter-relationship of between the capabilities of port sub-systems and the systems of different ports were subtle, complex and only apparent to certain stakeholders; usually the stakeholders who depended on their to enable their own roles in the wider UK ports system.

In addition to port operators and government regulators the other organisations that we interviewed also had limited information about phenomena that was outside of their experience or their ability to sense. For example, we were told that ship owners only know high level descriptions of the contents of containers on their ships; an abstraction of the full contents information. Some disasters and crises could never be predicted but even earthquakes have increased seismic events that could be a trigger for a heightened state of readiness in some specific locations and for some specific organisations. We were still left with the problem that certain key dependencies might be destroyed or removed from use - the secondary risks - and we could not predict when this might happen. But we now saw that stakeholders could start to list what these secondary risks are. And some stakeholders had more warning than others. For example, a port might have known exactly when a cargo was due to arrive, but not what was on it and how its 'provenance' affected the port's ability to service the cargo. But some other system stakeholder had this information.

Second, we found that every staff member of the organisations which we met with was under strong commercial pressure to use resources efficiently. This was true for commercial organisations with the objective of being economically profitable and most UK public sector organisations had recently been through several rounds of funding cuts (Wheeler, 2015). Commercial organisations wanted to keep certain information from their competitors to stop them learning how to operate more effectively or to stop competitors blocking future strategies. Firms did not want their customer to understand how profitable certain services were because this would impact price negotiations. For example, ship operators often sublet the cargo space to third parties; a shipping line might sublet 2000 slots to a freight forwarder. The freight forwarder might then sell the slots and Maersk would have no direct visibility of what the freight forwarder charged or what was in the slots. Detailed contents checking is done by a country's customers agency, not the ship owner. But a keen attention to how resources were used did not directly stop information flowing between organisations. What did stop information from flowing was never considering sharing information in the firm place. Our participants were in the business of government or port orchestration or logistics or transport. Limited resources drove a need to focus. There was information that they would not want to share for commercial privacy reasons but mostly they never considered sharing information.

Third, our research meetings and conversations with the DfT and Defra, and on one occasion DECC, highlighted the political reasons for not sharing information. There was the normal lack of a reason to do so in the first place - when they could think who or why it might be used - but for government departments there were additional constraints and responsibilities. In the UK ports system the government departments worked on the highest level, the national level. This gave them a 'view' of the whole system and potentially they had access to information from all stakeholders. But as we have already hinted at, to ask for something you have to know what to ask for. The ports system of stakeholders produced a vast stream of data as they work. To know which data are required government departments must first understand something about the need that this will satisfy. For example, the East Coast Ports Group was a valuable consultation vehicle (Powell, 2015).

Another political reason for not sharing information was to avoid unintended consequences. Government departments have access to vast data but their influence is also vast. Whether it was as obvious as changing a law or just a particular choice of words in a recorded conversation, there is great potential for unintended consequences. For example in 1988 the UK MP Edwina Currie said publicly that most of Britain's egg production was infected with salmonella bacteria. Sales of eggs fell sharply and the government had to offer financial compensation for the huge numbers of unsold eggs and unneeded hens (BBC, 2008). As a result of this sort of risk the civil servants that we talked to were very careful about what they said to us and very careful about what information they shared as a whole. The problem was the inference that might be taken or the use that official information might be used for, not the thing that is said. Even if a politician or a civil servant says what appears to be something sensible they still might get into trouble if their words or data are then used as raw 
material for some negative consequence. So they have to give very limited, qualified and precise communications - which constrains them.

Fourth, all the participants that we interviewed had very different information requirements (see Table IV).

\begin{tabular}{|c|c|c|}
\hline Stakeholder organisation & $\begin{array}{c}\text { Information needs in normal } \\
\text { operations }\end{array}$ & $\begin{array}{l}\text { Illustrative information needs } \\
\text { in a crisis }\end{array}$ \\
\hline $\begin{array}{l}\text { UK Government regulator, e.g. the } \\
\text { DfT or Defra }\end{array}$ & $\begin{array}{l}\text { Annual Maritime and port } \\
\text { statistics } \\
\text { Port locations and contact details } \\
\text { General port capacity data } \\
\text { Weather alerts/warnings } \\
\text { (applies to all categories of } \\
\text { stakeholders) }\end{array}$ & $\begin{array}{l}\text { Real-time statistics related to the } \\
\text { disruption and the commodities } \\
\text { imported at the effected ports and } \\
\text { across the UK } \\
\text { Emergency managers' contact } \\
\text { details; specific details about the } \\
\text { capacity of port operations } \\
\text { (number of pilots, \% capacity } \\
\text { dependent on pilots/tugs, vessel } \\
\text { schedules, berths, special } \\
\text { equipment requirements) } \\
\text { Live impacts of the crisis (e.g. } \\
\text { flooding): which parts of port(s) } \\
\text { are affected? Which operational } \\
\text { capabilities are affected? }\end{array}$ \\
\hline UK Port operator & $\begin{array}{l}\text { Ship arrival schedules } \\
\text { Vessels' specifications, goods } \\
\text { categories (e.g. hazardous } \\
\text { materials) } \\
\text { Pilotage and tug boat } \\
\text { requirements and requests } \\
\text { Services other than handling } \\
\text { required at port (e.g. } \\
\text { maintenance and bunkering) } \\
\text { Weather alerts and warnings }\end{array}$ & $\begin{array}{l}\text { Delays - caused by dynamic } \\
\text { schedule of arrivals and } \\
\text { departure decisions by shippers } \\
\text { including re-routed vessels from } \\
\text { other ports } \\
\text { Dynamically changing requests } \\
\text { for tugs and pilots based on } \\
\text { emergencies, the weather or for } \\
\text { rescue and salvage } \\
\text { Vessels' damage or condition, } \\
\text { e.g. oil leaks (for decisions about } \\
\text { repairx and allocation of berths) } \\
\text { Certainty of events, impacts of } \\
\text { flooding, what parts of the port } \\
\text { might be flooded, which } \\
\text { operations are affected for } \\
\text { response actions (e.g. moving } \\
\text { things to safer areas) } \\
\text { Wind data - for crane operations } \\
\text { If port operations are suspended } \\
\text { then data is required to decide } \\
\text { when to resume and for queue } \\
\text { management of waiting vessels } \\
\text { at anchorage outside the port } \\
\text { Land side access issues - } \\
\text { dynamic data about disruptions, } \\
\text { queuing of trucks, cancellations } \\
\text { of rail (so as to manage the sea- } \\
\text { side supplies). } \\
\text { Description of response actions } \\
\text { by external agencies such as the } \\
\text { Government/ Highways Agency, } \\
\text { railway operators and Network }\end{array}$ \\
\hline
\end{tabular}




\begin{tabular}{|c|c|c|}
\hline & & $\begin{array}{l}\text { Rail (also shipping lines and } \\
\text { importers) to dynamically fit } \\
\text { them to response measures of the } \\
\text { port }\end{array}$ \\
\hline Ship operator & $\begin{array}{l}\text { Terminal or berth allocations } \\
\text { Pilot or tug allocations } \\
\text { Traffic services in the navigation } \\
\text { channel } \\
\text { Bathymetry data for port, berth } \\
\text { dimensions (maximum draught } \\
\text { or length) } \\
\text { Terminal efficiency, turn-around } \\
\text { times } \\
\text { Availability of services } \\
\text { (maintenance, repair, bunkering } \\
\text { facilites) }\end{array}$ & $\begin{array}{l}\text { Berth availability (if operations } \\
\text { suspended) } \\
\text { Alternative berths or ports (their } \\
\text { specification and facilities) and } \\
\text { if importers could pick goods } \\
\text { from these locations } \\
\text { Dynamic weather data and } \\
\text { predictions } \\
\text { Ports reliability, safety standards } \\
\text { and emergency handling } \\
\text { practices }\end{array}$ \\
\hline $\begin{array}{l}\text { Importers, shipping agents and } \\
\text { logistics companies }\end{array}$ & $\begin{array}{l}\text { Ship arrivals or container arrival } \\
\text { schedule } \\
\text { Onward land logistics schedule } \\
\text { Customs and port health } \\
\text { declaration information }\end{array}$ & $\begin{array}{l}\text { Delays and related cost sharing } \\
\text { agreements } \\
\text { Destination and land logistics } \\
\text { diversion information for re- } \\
\text { routed ships } \\
\text { Land side access and disruption } \\
\text { management } \\
\text { Changes in information to } \\
\text { authorities and availability of } \\
\text { official government checking } \\
\text { facilities at selected ports }\end{array}$ \\
\hline
\end{tabular}

Table IV: Illustrative examples of the information needs of different UK ports resilience stakeholders for normal and crises operations

In Table IV we have illustrated how the information needs of different ports resilience stakeholders changes according to who they are and what their role is, i.e. it is subjective. Their information needs also changed between normal operations and operating in a crisis. We note that information needs are dependent on the form of crises as well as the role of the stakeholder, so Table IV is meant to be illustrative rather than exhaustive. In fact we only had room to show three groups of stakeholders. A lower level description, which looked at individual types of firms - for example importers, shipping agents and logistics companies - would show even more diverse information requirements. Information requirements differed significantly between stakeholders with different roles. For example, our two workshops in Immingham concerning pandemic flu and a bridge collapse on a main rail access point resulted in very different lines of enquiry (Immingham, 2013a, Immingham 2013b). The pandemic flu crisis scenario demanded information about staff availability, skill requirements, cross-skill training, port capacities and commercial service expectations. The bridge collapse scenario demanded information about the quality of alternative rail access infrastructure, rerouting options, repair bridge collapse time-frames, alternative transport modes (road/ship), backlog simulations, the fuel demands of the Drax power station and the available capacity at other coal terminals. The information needs of different stakeholders were also driven by dependencies. The stakeholders needed information depending on their roles on the port system and also dependent on the type of crisis and how it affected them.

\section{Discussion}

\subsection{Conceptualising the complexity of resilience planning in terms of information subjectivity}

From the data we found that many of the silos or barriers to information sharing came from the 'subjectivity' of the information itself. This was either the subjective experiences and knowledge of the person with the data, the potential data supplier, or the subjective needs for information that the potential information consumer. 
Different people and organisations had access to different data depending on their location, specialisation or other characteristics of their role. Different people and organisations needed different information depending on their role, but also depending on the specific crisis and how it affected their role and the part of the port system that they were responsible for. A theme that came up in our reflective conversations with port system stakeholders, and especially the DfT, was about the definition of a port. They said "What is a port?" or "They do not understand what a port is". Each stakeholder's interpretation of what a port was depended on their subjective experience of the port, their role in the port system, and what they saw and did. The distinction between how we use the terms 'data' and 'information' is in the relative specificity of these two terms. We use 'data' to mean a relativity broad dataset with a huge number of possible uses. We use 'information' to mean a specific set of data inputs that would enable a specific goal. This is similar to the concept of 'service-need' from Network Orchestration theory. A service-need is that which is fulfilled by a specific service (Shaw, 2007). Different ports stakeholders had different roles and experiences so they had access to different data and they needed different information. The network orchestrator, the 'keystone firm', the 'hub firm' or the network manager is a single organisation that influences the activities of a network of separate organisations (Iyer and Davenport, 2008; Dhanaraj and Parkhe, 2006; van Heck and Vervest, 2007; Moller and Svahn, 2006; Iansiti and Levien, 2004). In a port the port operator orchestrates the work of the many different port tenants and the firms that provide services to them. Other organisations sought to orchestrate higher levels of the UK ports system, for example the DfT.

The concept of information subjectivity is also consistent with the Value Creation literature which shows us that the process of value creation is subjective, i.e. the information that the people in our case needed depended on so many things that their needs were relatively unique (Lepak et al., 2007; Priem, 2007; Ramirez, 1999). Our focus was on information sharing but this insight may also be applicable to non-informational resources. Certainly it is applicable to the information required to access non-informational resources and subjectivity is a key part of providing personalised services (Vargo and Lusch, 2004; Vargo and Lusch, 2008). Our investigation suggested that the information needs of port resilience planners can be considered as a service and that this service should be personalised according a large number of dependencies.

There are several references to the complexity of disaster resilience situations in the literature (Welsh, 2014; Comfort et al., 2001), but our investigation has highlighted how this complexity is produced. Complex systems differ from complicated systems not necessarily because they have more elements but because they have more interrelations. These interrelations act as feedback loops which produce non-linear characteristics (Allen et al., 2003). Complexity comes from the number of possible relationships not from the number of elements that are related. In ports systems there are a large number of stakeholders but resilience planning was made complex by the many dependencies that stakeholders had to deal with. Dependencies such as the type and timing of a disaster; what part of the port system it affected; how it affected it and how this was mitigated or amplified by other characteristics of the larger system of UK or global ports. In the UK, severe delays to all traffic moving to and from the port of Dover in 2015 were caused by striking workers from the Dover-Calais ferry operator MyFerryLink. MyFerryLink was operated by Eurotunnel, the owner of the Channel Tunnel. But Eurotunnel was banned from operating MyFerryLink by the UK's Competition Commission. Unfortunately, when Eurotunnel said it would sell its two ferries to a competitor the MyFerryLink workers feared for their jobs and blockaded the port of Calais (BBC, 2015a). This crisis was caused by complex interrelations between competition law, company strategy, asset ownership and the relative capacity of different parts of the UK ports system. The different stakeholders included the UK's competition regulator, a tunnel operator and a ferry operator, workers and two ports in two countries. The result of these complex interdependencies was difficult to forecast by the UK's completion regulator at the time that it made its decision, and from its subjective position the decision was logical as well as legally necessary.

Port resilience planning information is subjective. Different stakeholders possess different data because of their subjective positions, i.e. their roles, their levels in the ports system, their social network and the different information systems that they use. Different stakeholders also have different needs for information in resilience planning, for the same reasons. They have different roles, they work on different levels in the ports system, they are part of different social networks and use different information systems.

\subsection{Conceptualising the complexity of resilience planning information terms of subjective loss of capability}

Our conceptualisation of the subjectivity of the different data that is possessed by ports resilience stakeholders, and the subjectivity of their information needs, helps us to understand the basis of some of the siloes that we witnessed. It is one way to view the many dependencies that cause complexity in resilience planning and it suggests ways to remove silo walls. Information production and use is a two-sided process that has similarities to process modelling (Curtis et al., 1992)) and service production (Vargo and Lusch, 2004; Vargo and Lusch, 
2008). In our study data inputs were converted into insight outputs by some process and the value of the outputs depended on the subjective requirements of the consumer.

For resilience planning purposes the disaster or crisis cannot be forecast so all types of disaster must be planned for. Planning for any emergent possibility is impossible but we can remove some of this complexity by focusing on planning for some subjective loss of capability. Subjective loss of capability simply means the loss of some capability that one port stakeholder's role is dependent on. The stakeholder could be a system actor on any level, i.e. a worker or manager; a team or department, a logistics firm or a port operator; or a government department or a regulator. We avoid the emergent complexity of having to forecast the type of disaster by thinking about the outcome of a disaster rather than the disaster itself. Thinking about information flows in terms of the subjective needs of whoever is planning for resilience avoids complexity by distributing it. A manager that is responsible for a particular delivery route will need information on secondary risks for that route. A ferry operator that runs ferries between Dover and Calais will only need to focus on what is needed to maintain the capability of running that service. We use the term 'capability' rather than 'capacity' because capacity is used more in a sense or the measure of a degree or amount whereas our study investigated logical type.

We think of the linked capabilities of people and organisations in terms of the 'flow paths' of cargoes from international waters, through ports and on into port hinterlands and the routes of UK supply chains by road and rail. Flow paths are the physical routes of goods from farm to retail store. They are the linked capabilities that grow, process and transport foods from agri-subsystems to consumers. Alternative flow paths are required when capabilities are lost due to crises. Capabilities are anything that processes a cargo through stages, that are on any scale. Scales from the skills of an individual person, to a specific vehicle or piece of machinery, on up to the capabilities of a whole firm or supply chain. A similar argument explains the flow paths of passengers all along their journeys.

The concept of subjectivity, in the form of flow paths, provides an opportunity to decouple dependencies and so to reduce the emergent complexity of information sharing in resilience planning. Instead of thinking of planning for some unspecified disaster that affects a whole system we saw that each system stakeholder, at any level, can focus on their own stage of the flow paths that they are responsible for. Then they can specify what data they can supply, as well as what information they need, in terms of the capabilities of their stage to help goods and passengers flow.

\subsection{Avoiding information flow silos using information subjectivity}

In our case study we found several types of information flow silos that were caused by the emergent complexity of linked dependencies. It was not so much that dependencies caused silos, more that given certain events linked sets of dependencies caused a need for information sharing, where there was no systematic method or practice of doing do. But by thinking of how information flows in terms of the subjective capabilities of data suppliers and the subjective needs of the information users it is possible to suggest ways to avoid or at least minimise barriers to sharing resilience information. Next we will do this for each type of silo that we highlighted earlier:

- Forecasting - disasters and crises are unforecastable but it is possible to plan for resilience in terms of the removal of the specific capabilities that each stakeholder is responsible for.

- Key dependencies - key dependencies are inter-related in complex ways and largely unmapped. But focusing on specific flow path stages and their capabilities filters out much of this complexity by removing some inter-relations.

- Commercial confidentiality - firms are rightly sensitive to uses of their data that might harm them in some way. But being highly specific about who, how and why information can be used could reduce their sensitivity to sharing information - especially if their commercial interests are harmed by a removal of a capability on their flow path. Also, abstracting the data to turn it into meta data, i.e. a description of the data held, preserves its availability whilst limiting inappropriate use.

- Never considering sharing some data in the first place - only information users can guess the use, data suppliers cannot. This partly explains what Bharosa et al. called "lack of incentives" (2009), one of their obstacles to sharing information in resilience situations. Sharing meta data on who has what data in terms of flow path capabilities enables the information users to take the initiative and ask the potential data providers. The biggest silo we found was awareness of who has what data.

- Political sensitivities: unintended consequences can be avoided in a similar way to avoiding commercial harm. Being highly specific about who, how and why data can be used could reduce the political sensitivity. Also, abstracting the data to turn it into meta data, i.e. a description of the data held, preserves its availability whilst limiting inappropriate use. 
- Too much data, which data are required by which users? - ports stakeholders had highly specific information requirements but and exposing them to too much data risks 'information overload' A focus on the capability of specific flowpath stages filters out much data and reduces this risk.

Information subjectivity reduces the barrier of awareness of who has what data and the sensitivities of control over its use by viewing these problems in terms of their own context. Each problem is one of dependencies and suggests questions like 'who has the data?', 'what type of crisis?', 'what is the use?' and 'who would use it?'. If we think in terms of the port system capabilities that are removed then we can decouple the need for information from the type of disaster and focus on a subset of potential data suppliers (Orton and Weick, 1990). Also, we can distribute the problem and the solution and thereby remove many inter-dependencies by being specific about the use of the information rather than leaving this to be unspecified and potentially inappropriate.

Furthermore, our concept of information subjectivity is consistent with the literature on data privacy. Different people have different attitudes to the use of their data (Lewis and Liao, 2014). And people even have different attitudes to the same data, based on different dependencies. This later point is called the 'privacy paradox' and it is when people start off intending to keep their personal data secret but they then still share it (Bélanger and Crossler, 2011). Privacy research is a growing area of the information systems literature, although much of the work is on firm's use of individual's data rather than business-to-business data confidentiality. But subjectivity plays a key role because privacy attitudes are highly dependent on the specific contexts of data sharing or data use (Smith et al., 2011).

\section{Conclusions}

\subsection{Contributions for researchers}

Information sharing in port resilience planning is an emerging area of the disaster resilience literature and this study adds to it in several ways. First, it shows a way to organise data for port resilience planning purposes that avoids some of the barriers to information sharing in the literature and that we saw in our case. We show the supply-side and the demand-side perspectives of information sharing. They show how to make information sharing complicated rather than complex by removing some of the dependencies that cause emergent complexity. The concept of information subjectivity can be used to filter out all dependencies except for those that some specific outcome depends upon.

The concept of specific loss of capability provides a way to specify the outcome for each individual stakeholder at any organisational or system level. And a capability-based perspective supports the basic aims of port resilience planning. Second, our emphasis on personalised local issues, outcomes and subjectivity - rather than general global issues, diverse potential inputs and a standardised perspective - implies two other advantages. One advantage is that we avoid the information overload problem that would stop an information user from finding the specific information that they needed. Also, representing information in terms of flowpaths of capabilities provides a framework for matching data suppliers with information users. Each flowpath can be drawn on a map, at any scale, to give a shared context. Another advantage is that this approach avoids some of the potential political and commercial sensitivities that would stop a data supplier from sharing. By being quite precise about the information, and how it must be used, the potential for inappropriate use is reduced. Third, it extends the disaster resilience literature and the port resilience planning literature into the information sharing literature, and it supports policy-making. Fourth, our study links the disaster resilience literature to the Value Creation literature and the Servitization literature with the very useful concept of the subjectivity and the conceptualisation of resilience planning as a set of services.

\subsection{Contributions for practitioners}

Our investigation provides a method for promoting greater resilience and integration by sharing information across levels and along the supply chain. We find that the motivation for practitioners is that smooth operations during a crisis is supported by smooth operations during normal business. Resilience is a specific application of information sharing that motivates stakeholders to participate for sound business reasons in addition to a need for resilience. In our study we asked stakeholders what information they needed to plan resilience (their alternatives) and part of this was information that would have significantly helped their businesses. Information sharing can be used to improve the operation of the whole system by more precisely using all resources, i.e. reducing waste and increasing the personalisation of products and services for firms and their staff.

Our investigation has suggested how to help to orchestrate information sharing across the system so that when disasters occur there are alternatives, patches, work-arounds and higher-level helpers to call on. Orchestrating information sharing means (a) a centralised method of information sharing that is used in a decentralised way; and (b) using stakeholders' subjective needs for more information to motivate participation. Helping 
stakeholders to access the information they need helps them to work more effectively themselves and with other system stakeholders. For example, our work with port stakeholders has highlighted examples such as getting earlier warnings of disruptions or demand spikes so they can better manage labour planning; or opportunities to better share scarce resources, like berths or access roads in a 'pool' so as to get higher utilisation percentages. Orchestration approaches help to increase system capacity by reducing waste at each level. Orchestrated information sharing benefits policy-makers and regulators by helping them to decide when to use their limited resources and when to intervene.

\subsection{Limitations and Future Research}

We chose the case system as an extreme case because it had multiple levels of organisation for a whole country (Eisenhardt, 1989). Furthermore, we were lucky enough to have detailed longitudinal research access to staff whose roles included country-wide resilience planning. A single case reduces the possibility of generalisation (Lee, 1989), but our case was special in the sense that it concerned a whole country from the level of government to the level of individual port stakeholder firms. This enabled us to investigate the structure and processes of information flows that other case sites would not provide (Siggelkow, 2007).

However, a single country case site limited our research and we did not explore the higher international levels of the global ports system. This limitation points to further research to investigate if the phenomena and relationships that we have seen are repeated in other countries and at international levels; and if our theoretical constructs make sense at these levels. Our research strategy helped us to deal with some of the complexities of ports' systems by using a cyclical process of generating and testing ideas with triangulation at multiple levels and using multiple perspectives over a long time period. Our hermeneutical process was useful and plausible because of the very large amount of reflection and checking of our findings by diverse ports' stakeholders. But it might have been quicker to use other methods of reflection and validation that use larger 'innovate and check' cycles, such as Action Research (Baskerville and Myers, 2004). Action Research may be more appropriate for actually implementing some IT solution to enable information sharing in this context, because it is designed for researchers to intervene as participants in their own research in order to make changes and to learn from the process.

\section{Acknowledgements}

We were extremely fortunate to have support from the DfT's exHead of Resilience Planning and Consequence, Mike Davies, and from his successor Miles Gidlow, Maritime Resilience Policy Manager at the Department for Transport, who both helped us with information, introductions, validation and secure access to DfT related information and personnel; the regulators of other critical UK infrastructure (e.g. the Department for Environment, Food \& Rural Affairs); and most importantly the commercial firms and other organisational stakeholders in the running of the UK's ports. The DfT and commercial stakeholders validated our findings at each stage in keeping with our method. This work was also funded by the EPSRC IDEAS Factory project (EP/I005935/1); the EPSRC Impact Acceleration Programme (IAP-KTS-0915a); a UoN Hermes Travel Bursary; the ESRC IAA Impact Accelerator Fund; and a DfT/ESRC/UoN PhD studentship.

\section{References}

Achuthan K, Zainudin N, Roan J, and Fujiyama T (2015) Resilience of the Food Supply to Port Flooding on East Coast (FO0454), Defra, UK.

Akakura Y, Ono K, Watanabe T and Kawamura H (2015) Estimation of alternative ports for container transport after large-scale disasters - Estimation method and application to port-BCPs, Journal of Integrated Disaster Risk Management, 5 (2), 135-152.

Aldunce P, Beilin R, Handmer J and Howden M (2014) Framing disaster resilience The implications of the diverse conceptualisations of "bouncing back, Disaster Prevention and Management, 23 (3), 252-270.

Allen DK, Karanasios S and Norman A (2014) Information sharing and interoperability: the case of major incident management, European Journal of Information Systems, 23, 418-432.

Allen TFH, Tainter JA,. HoekstrA TW (2003) Supply-Side Sustainability, Columbia University Press.

Bahadur AV, Ibrahim M and Tanner T (2013) Characterising resilience: unpacking the concept for tackling climate change and development, Climate and Development, 5 (1), 55-65.

Baskerville R and Myers MD (2004) Special issue on Action Research in Information Systems: Making IS Research relevant to practice-Foreword, MIS Quarterly, 28(3), 329-335.

BBC (2008) 1988: Egg industry fury over salmonella claim, BBC News, 
http://news.bbc.co.uk/onthisday/hi/dates/stories/december/3/newsid_2519000/2519451.stm,accessed March 2016.

BBC (2015a) Ferry services resume after Calais port blockade, BBC News,

http://www.bbc.co.uk/news/uk-34104336, accessed March 2016.

BBC (2015b) Channel Tunnel services resume after migrant break-in, BBC News, http://www.bbc.co.uk/news/uk-34432386, accessed March 2016.

Becker A and Caldwell MR (2015) Stakeholder perceptions of seaport resilience strategies: A case study of Gulfport (Mississippi) and Providence (Rhode Island), Coastal Management, 43 (1), 1-34.

Bélanger F and Crossler RE (2011) Privacy in the digital age: a review of information privacy research in information systems, MIS Quarterly, 35 (4) 1017-1041.

Benbasat I, Goldstein DK and Mead M (1987) The case research strategy in studies of information systems, MIS Quarterly, 11 (3), 369-386.

Bhamra R, Dani S and Burnard K (2011) Resilience: the concept, a literature review and future directions, International Journal of Production Research, 49 (18), 5375-5393.

Bharosa N, Lee JK and Marijn Janssen M (2010) Challenges and obstacles in sharing and coordinating information during multi-agency disaster response: Propositions from field exercises, Information Systems Frontiers (2010) 12, 49-65.

Chalmers M (2004) Hermeneutics, information and representation, European Journal of Information Systems, 13 (3), 210-220.

Comfort LK, Sungu Y, Johnson D and Dunn M (2001) Complex Systems in Crisis: Anticipation and resilience in dynamic environments, Journal of Contingencies and Crisis Management, 9 (3), 144-158.

Chen R, Sharman R and Chakravarti N (2008) Emergency response information system interoperability: development of chemical incident response data model, Journal of the Association of Information Systems, 9 (3/4), 200-230.

Chewning LV, Lai C-H, and Doerfel ML 2012 () Organizational resilience and using information and communication technologies to rebuild communication structures, Management Communication Quarterly, 27(2), 237-263.

Crichton MT, Ramsay CG and Kelly T (2009) Enhancing organizational resilience through emergency planning: learnings from cross-sectoral lessons, Journal of Contingencies and Crisis Management, 17 (1), 2437.

Curtis B, Kellner MI and Over J (1992) Process Modelling, Communications of the ACM, 35 (9).

Davies M (2014) Planning for the worst - an agenda for recovery. How ports and their local resilience partners must plan to prepare for and recover from inundation by a North Sea tidal surge, Department for Transport.

DfT (2011) Transport Statistics Great Britain 2011: Maritime, Transport Statistics Great Britain, Department for Transport, www.gov.uk/government/publications/tsgb-2011-maritime, accessed March 2016.

DfT (2012) UK Port Freight Statistics: 2011 final figures, London, Department for Transport, https://www.gov.uk/government/uploads/system/uploads/attachment_data/file/9257/port-freight-statistics-final2011.pdf, accessed March 2016.

Eisenhardt M (1989) Building theories from case study research, Academy of Management Review, 14 (4), 532 550.

Gardiner J (2002) What is Cobra?, The Guardian, www.theguardian.com/politics/2002/oct/21/Whitehall.uk, accessed 18 February 2016.

Grainger A and Achuthan K (2014) Port Resilience: A Primer, research validation document produced to brief senior officials across Whitehall and Ministers, also used by the Environment Agency as a training resource, http://eprints.nottingham.ac.uk/2279, accessed March 2016.

Highways England (2015) Operation Stack: consultation on new lorry area launches today, Highways England and Andrew Jones MP, https://www.gov.uk/government/news/operation-stack-consultation-on-new-lorry-arealaunches-today, accessed March 2016. 
Hsieh C-H, Tai H-H and Lee Y-N (2014) Port vulnerability assessment from the perspective of critical infrastructure interdependency, Maritime Policy \& Management, 41 (6), 589-606.

Iansiti M and Levien R (2004) Strategy as ecology, Harvard Business Review, March, 68-78.

Ibrahim NH and Allen D (2012) Information sharing and trust during major incidents: findings from the oil industry, Journal of the American Society for Information Science and Technology, 63(10), 1916-1928.

Immingham (2013a) Multi-stakeholder workshop to test reactions to a Pandemic flu outbreak at Port of Immingham, UK, September.

Immingham (2013b) Multi-stakeholder workshop to test reactions to a major bridge collapse effecting Port of Immingham, UK, September.

Iyer B and Davenport TH (2008) Reverse Engineering Google's Innovation Machine, Harvard Business Review, 86 (4), 58-68.

Kent Police (2016) Operation Stack M20, Kent Police, http://www.kent.police.uk/news/latest_news/000000_op_stack.html, accessed March 2016.

Klein HK, and Myers MD (1999) A Set of Principles for Conducting and Evaluating Interpretive Field Studies in Information Systems, MIS Quarterly, 23 (1), 67-93.

Lee AS (1989) A scientific methodology for MIS case studies, MIS Quarterly, 13 (1), 33-50.

Lepak DP, Smith KG and Taylor MS (2007) Value Creation and Value Capture: A Multilevel Perspective, Academy Of Management Review, 32 (1), 180-194.

Lewis H and Liao C (2014) Data Nation: Putting customers first, Deloitte,

http://www2.deloitte.com/content/dam/Deloitte/uk/Documents/deloitte-analytics/deloitte-uk-data-nation2014.pdf.

Loh H and Thai V (2015) Managing port-related supply chain disruptions (PSCDs): a management model and empirical evidence, Maritime Policy \& Management, 1-20.

Mansouri M, Nilchiani R and Mostashari A (2010) A policy making framework for resilient port infrastructure systems, Marine Policy, 34 (6), 1125-1134.

Manyena SB (2006) The concept of resilience revisited, Disasters, 30 (4), 433-450.

Manyena SB and Gordon S (2014) Bridging the concepts of resilience, fragility and stabilisation, Disaster Prevention and Management, 24 (1), 38-52.

Manyena SB, O'Brien G, O'Keefe P and Rose J (2011) Disaster resilience: a bounce back or bounce forward ability?, Local Environment, 16 (5), 417-424.

Moller K and Svahn S (2006) Role of Knowledge in Value Creation in Business Nets, Journal of Management Studies, 43 (5), 985-1007.

Norris FH, Stevens SP, Pfefferbaum B, Wyche KF and Pfefferbaum RL (2008) Community resilience as a metaphor, theory, set of capacities and strategy for disaster readiness, American Journal of Community Psychology, 41, 127-150.

Orton JD and Weick KE (1990) Loosely Coupled Systems: A Reconceptualization, The Academy of Management Review, 15, (2), 203-223.

Paul JA and Maloni MJ (2010) Modeling the effects of port disasters, Maritime Economics and Logistics, 12 (2), 127-146.

PLA (2016a) Definitive berth names, Port of London Authority, https://www.pla.co.uk/Safety/Hydrography/Definitive-Berth-Names, accessed March 2016.

PLA (2016b) List of moorings, Port of London Authority, http://www.pla.co.uk/Leisure/List-of-Moorings, accessed March 2016.

Powell D (2015) East Coast Flood Group Review Report, final version, 17 September 2015.

Priem RL (2007) A Consumer Perspective on Value Creation, The Academy of Management Review, 32 (1), 219-235.

Ramirez R (1999) Value co-production: intellectual origins and implications for practice and research, Strategic Management Journal, 20, 49-65. 
Robson C (2002) Real World Research, Oxford: Blackwell, 2nd ed.

Roth WD and Mehta JD. 2002. The Rashomon Effect combining positivist and interpretivist approaches in the analysis of contested events, Sociological Methods and Research 31 (2), 131-17.

Shaw DR (2007) Manchester United Football Club: developing a Network Orchestration Model, European Journal of Information Systems, 16 (5), 628-642.

Siggelkow N (2007) Persuasion with case studies, Academy of Management Journal, 50 (1), 20-24.

Simon HA (1997) Administrative Behavior. A Study of Decision-Making Processes in Administrative Organizations, Fourth Edition, The Free Press, Simon \& Schuster, New York.

Smith HJ, Dinev T, Xu H (2011) Information privacy research: An interdisciplinary review, MIS Quarterly, 35 (4), 989-1015.

UN/ ISDR (2007), Hyogo Framework for Action 2005-2015: Building Resilience of Nations and Communities to Disasters, United Nations International Strategy for Disaster Reduction, Geneva.

Vargo SL and Lusch RF (2004) Evolving to a new dominant logic for marketing. Journal of Marketing, 68(1), $1-17$.

Vargo SL and Lusch RF (2008) Service-dominant logic: continuing the evolution. Journal of the Academy of Marketing Science, 36(1), 1-10.

Welsh M (2014) Resilience and responsibility: governing uncertainty in a complex world, The Geographical Journal, 180 (1), 15-26.

Wheeler B (2015) Spending Review: Department-by-department cuts guide, BBC, http://www.bbc.co.uk/news/uk-politics-34790102, accessed March 2016.

Yin RK (2003) Case Study Research: Design and Methods, Third Edition, Applied Social Research Series, Volume 5, Sage. 